\title{
Proximate Composition and Chemical Profiles of Reishi Mushroom (Ganoderma lucidum (Curt: Fr.) Karst)
}

\author{
T. Garuba ${ }^{1 *}$, G. S. Olahan ${ }^{1}$, A. A. Lateef ${ }^{1}$, R. O. Alaya ${ }^{1}$, M. Awolowo ${ }^{2}$, A. Sulyman ${ }^{3}$ \\ ${ }^{1}$ Department of Plant Biology, University of Ilorin, Nigeria \\ ${ }^{2}$ Department of Biology, National Open University of Nigeria, Nigeria \\ ${ }^{3}$ Department of Animal Health Production, Federal College of Wildlife Management, New-Bussa, \\ Nigeria
}

Received 30 June 2019, accepted in final revised form 25 September 2019

\begin{abstract}
Ganoderma lucidum is a mushroom commonly used in folk medicine especially Traditional Chinese Medicine (TCM) but information on its nutritional and chemical profiles remains insufficient. This work aimed at evaluating proximate composition and identification of bioactive compounds in ethanolic extract of G. lucidum. Pulverized G. lucidum was suspended in ethanol in 1:10 and extraction was carried out by rotary evaporation to produce G. lucidum extract (GLE). Proximate composition of the sample was analyzed. Fourier Transform Infrared (FTIR) spectroscopy was carried out to identify different functional groups in GLE. Gas Chromatography-Mass Spectrometry (GC-MS) was used to determine the bioactive compounds of the sample. Proximate analysis revealed that the amount of carbohydrate in sample was the highest $(44.95 \%)$, followed by protein $(15.75 \%)$. FTIR results showed that $\mathrm{OH}, \mathrm{C}=\mathrm{O}, \mathrm{C}-\mathrm{OH}, \mathrm{N}-\mathrm{H} 1 *$ and $2 *$ and alkyl halide are functional groups in GLE. A total of twelve (12) bioactive compounds were identified and the most prevailing compound in GLE was ethyl octadeca-9,12-dienoate (45.95\%), followed by ethylhexadecanoate / ethyl palmitate (18.09\%). Guaiacol (4.95\%), octadecanoic acid $(5.37 \%)$, ethylcyclohexane $(3.31 \%)$ were also present. It can be inferred from this study that G. lucidum is nutritional and contains bioactive compounds that are useful in nutraceutical and pharmaceutical industries.
\end{abstract}

Keywords: Bioactive compounds; Chemical profile; Functional group; Mushroom.

(C) 2020 JSR Publications. ISSN: 2070-0237 (Print); 2070-0245 (Online). All rights reserved. doi: http://dx.doi.org/10.3329/jsr.v12i1.42059

J. Sci. Res. 12 (1), 103-110 (2020)

\section{Introduction}

Mushrooms are a group of macro-fungi with conspicuous epigenous or hypogenous fruiting bodies [1] and have been valued throughout the world as both food and medicine for thousands of years [2]. Ganoderma lucidum (Curt: Fr.) Karst. (Common names:

\footnotetext{
* Corresponding author: garuba.t@unilorin.edu.ng
} 
Lingzhi or Reishei) belongs to phylum Basidiomycota and Family Ganodermataceae of Aphyllophorales [3]. It is called white rot fungus because of its ability to degrade lignocellulosic materials such as wood [4]. The mushroom is popular due to its pharmaceutical importance rather than its nutritional benefits because of its hard texture and bitter taste [5].This group of mushrooms is an underutilize source of bioactive pharmaceutical compounds [6]. The mushroom is used in folk medicine to prevent, manage or cure many diseases such as hepatitis, gastric ulcer, hypertension, bronchitis and hypercholesterolemia [7]. Biomedical investigations in China, Korea, Japan and USA revealed that the extraction of bioactive compounds such as triterpenes and polysaccharides from Ganoderma are good in preventing and treating medically important diseases including hypertension, diabetes, cancer and Acquired Immunodeficiency Syndrome (AIDS) [4]. Antibacterial activity of G. lucidum extract from basidiocarp against Gram-positive bacteria has also been reported [8]. Chinese believes that $G$. lucidum contributes to longevity and also serve as therapeutic factory [5]. DNA protection from breakage of strand triggered by UV irradiation or hydroxyl radicals is another protective role of G. lucidum [9].

Nutritionally, mushrooms provide many of dietary benefits found in meat, bean and grains [2]. Vegetarians take mushroom as an integral part of their meal. Fresh G. lucidum contains about $90 \%$ moisture and the residual $10 \%$ consist of ash $(8-10 \%)$, protein (10$40 \%$ ), fat (28\%), carbohydrate (3-28\%) and fibre (3-32\%) [10]. It was reported that wild and artificially cultivated $G$. lucidum have similar nutritional component although extraction significantly increase the amount of carbohydrate and crude protein [11]. Polysaccharides in the mushroom contains glucose, mannose, xylose, fucose galactose and arabinose as monomers that contribute significantly to its antitumor, antioxidant and antibacterial properties [12].

G. lucidum fungus is an important mushroom and majority of researches had been centered on its traditional benefits and role in folk medicine. Information on its chemical profile remains obscure. This study aimed at evaluating the proximate composition and chemical profiles of ethanolic extract of G. lucidum.

\section{Experimental}

\subsection{Sample collection}

The mushroom (Ganoderma lucidum) samples were collected at Faculty of Management Science Area, University of Ilorin, Kwara State, Nigeria. The taxonomy of the samples was authenticated in the Herbarium unit, Department of Plant Biology, University of Ilorin. The samples were collected in a polythene bag, sliced and air-dried in the laboratory at $25 \pm 2{ }^{\circ} \mathrm{C}$ for two weeks to a constant weight. They were pulverized using sterilized pestle and mortar. 


\subsection{Preparation of Ganoderma lucidum extract (GLE)}

The pulverized samples of Ganoderma lucidum ( $800 \mathrm{~g}$ ) were suspended in $8 \mathrm{~L}$ of ethanol for $72 \mathrm{~h}$ with continuous shaking by orbital shaker at $3000 \mathrm{rpm}$. The solution obtained was filtered with Whatman No. 4 filter paper and the resulting filtrates were evaporated in rotary evaporator at $50{ }^{\circ} \mathrm{C}$ to remove the extractant. The G. lucidum extract (GLE) was then stored at $4{ }^{\circ} \mathrm{C}$ for further use.

\subsection{Proximate analysis of Ganoderma lucidum}

Proximate composition of Ganoderma lucidum was determined using standard procedures of Association of Official Analytical Chemists [13]. Moisture was determined by water loss due to drying at a temperature of $105{ }^{\circ} \mathrm{C}$. While crude protein was estimated by the Kjeldahl method, the crude fat was determined by extraction of a known weight of sample with petroleum ether using Soxhlet apparatus. The defatted sample was used to determine crude fibre. Carbohydrate was determined by difference.

\subsection{Fourier Transform Infrared (FTIR) Spectroscopy}

The GLE was analyzed to identify the types of chemical bonds (functional groups) present in the sample by FTIR (Thermo scientific Nicolet iS5 with iD1 transmission) spectrophotometer using $\mathrm{KBr}$ disc in the range of $4000 \mathrm{~cm}^{-1}$ to $400 \mathrm{~cm}^{-1}$. A drop of the GLE was encapsulated with $\mathrm{KBr}$ pellet in order to prepare a translucent sample disc which was loaded in FTIR spectrometer.

\subsection{Gas Chromatography-Mass Spectrometry (GC-MS)}

The GC-MS analysis of GLE was carried out using Agilent Technologies 7890A Gas Chromatograph equipped to a mass detector Agilent Technologies 5975C inert MSD with Tripple-Axis Detector, $30 \mathrm{~m} \times 0.25 \mathrm{~mm}$ ID x $1 \mu \mathrm{m}$ of capillary column. The instrument was set to an initial temperature of $110{ }^{\circ} \mathrm{C}$ and maintained at this temperature for $2 \mathrm{~min}$. At the end of this period the oven temperature was increased up to $280^{\circ} \mathrm{C}$, at the rate $5^{\circ} \mathrm{C} / \mathrm{min}$, and maintained for $9 \mathrm{~min}$. injection port temperature was ensured as $250{ }^{\circ} \mathrm{C}$ and Helium flow as one $\mathrm{mL} / \mathrm{min}$. The ionization voltage was $70 \mathrm{eV}$. The samples were injected in spilt mode as 10:1. Mass spectral scan range was set at $45-450(\mathrm{~m} / \mathrm{z})$.

Using computer searches on a National Institute Standard and Technology (NIST Ver. 2.1 MS) data library and comparing the spectrum obtained through GC-MS, compounds present in the sample were identified. The names, retention time, molecular formula of the bioactive compounds were ascertained. 


\section{Results and Discussion}

\subsection{Proximate composition of Ganoderma lucidum}

The results of the proximate analysis revealed that the amount of carbohydrate in the sample mushroom was the highest $(44.95 \%)$, followed by protein $(15.75 \%)$. Ash had the lowest quantity of $4.00 \%$. The amount of crude fibre and moisture were $14.81 \%$ and $12.99 \%$ respectively (Fig. 1). The results agreed with the report which stated that carbohydrate and crude protein are the most abundant nutrient in G. lucidum [12]. The percentage of protein is similar to $15.04 \%$ as reported [14] and it is an indication that $G$. lucidum is a good source of protein despite that the fruiting bodies are corky, tough and thick. As a result of this, the mushroom can be used as a protein dietary supplement for both man and livestock [15]. The percentage of crude fat was found to be higher compared to previous studies $[14,15]$. The difference may be due to the nature of substrate, the part samples, habitat and place of sample collection [16]. Generally, mushrooms are called low fat calorie food which is attributed to high fibre content, no free fatty acids and no cholesterol [17]. The presence of a reasonable amount of fibre in $G$. lucidum facilitates movement of bulk via digestive track and averts constipation [18].

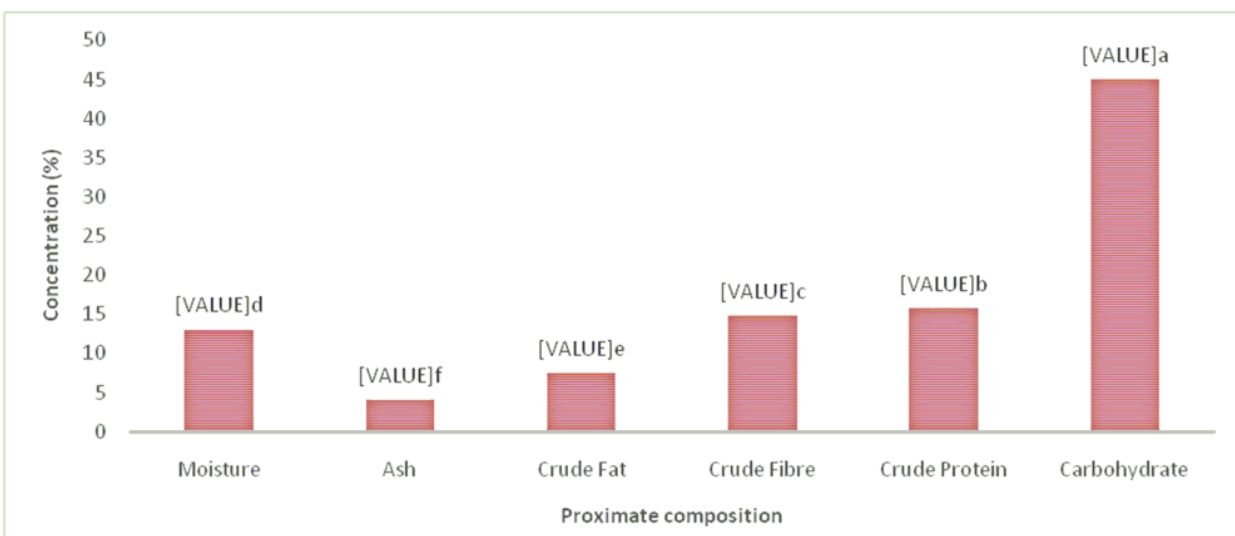

Fig. 1. Proximate composition of Ganoderma lucidum.

\subsection{Fourier Transform Infrared Spectrophotometry (FTIR) of GLE}

The observed peak positions from the FTIR spectroscopy of Ganoderma lucidum are summarized in Table 1. The peak at $3563 \mathrm{~cm}^{-1}$ is assigned to the $-\mathrm{OH}$ bond of water. The peak at $2926.65 \mathrm{~cm}^{-1}$ correspond to $-\mathrm{CH}$ stretch of alkane or $-\mathrm{OH}$ bond of carboxylic acid. The peak at $1720.32 \mathrm{~cm}^{-1}$ is due to $\mathrm{C}=\mathrm{O}$ stretch of carbonyl. $\mathrm{C}=\mathrm{C}$ stretch is responsible for the peak at $1460.69 \mathrm{~cm}^{-1}$. The observed peak at $1042.70 \mathrm{~cm}^{-1}$ may be due to $\mathrm{C}-\mathrm{OH}$ of carboxylic acid. The peak at $735.62 \mathrm{~cm}^{-1}$ is associated to primary and secondary amine while alkyl halide is responsible for the peak at $637.47 \mathrm{~cm}^{-1}$. These 
results indicate that sample contain alkyl halides, alcohols, esters, carboxylic acids, ethers, alkenes and amine compounds. The presence of carboxylic acids, amine and halogens may be responsible for medicinal properties of the extract [19].

Table 1. FTIR peaks of Ganoderma lucidum and the assigned bonds.

\begin{tabular}{ll}
\hline Wave number $(\mathrm{cm})$ & Assigned bonds \\
\hline 3563.00 & OH of alcohol \\
2926.65 & CH stretching alkane \\
1720.32 & $\mathrm{C}=\mathrm{O}$ stretch of carbonyl \\
1460.69 & $\mathrm{C}=\mathrm{C}$ stretching \\
1042.74 & $\mathrm{C}-\mathrm{OH}$ of carboxylic acid \\
735.62 & N-H $1 *$ and $2 *$ amine \\
637.47 & Alkyl halide \\
\hline
\end{tabular}

\subsection{Gas Chromatography-Mass Spectrometry (GC-MS) of GLE}

The GC-MS chromatogram showed the absorbance level of each compound along with time (Fig. 2). The GC-MS analysis of GLE revealed twelve (12) compounds from the gas chromatography fraction of ethanolic extract of the sample. While the bioactive compounds with their retention time, peak or concentration (\%), molecular formula and molecular weight are presented in Table 2, the biological activities and chemical nature of each bioactive compound are summarized in Table 3. The major and most prevailing active compound in GLE was ethyl octadeca-9,12-dienoate at RT of 39.99 with the peak of $45.95 \%$. This polyenoic fatty acid compound is biologically recognized for its lowering cholesterol level and ability to prevent liver damage [20]. Ethyl hexadecanoate (ethyl palmitate) was the second most abundant compound (18.09\%) in GLE at RT of 38.89. It is a stearic acid with antimicrobial property [21]. G. lucidum had previously reported to contain arrays of bioactive compounds that are therapeutically important such as alkaloids, steroids, polysaccharides and fatty acids [22]. This quality makes this Reishi mushroom gain ground in Tradition Chinese Medicine (TCM) [7]. 


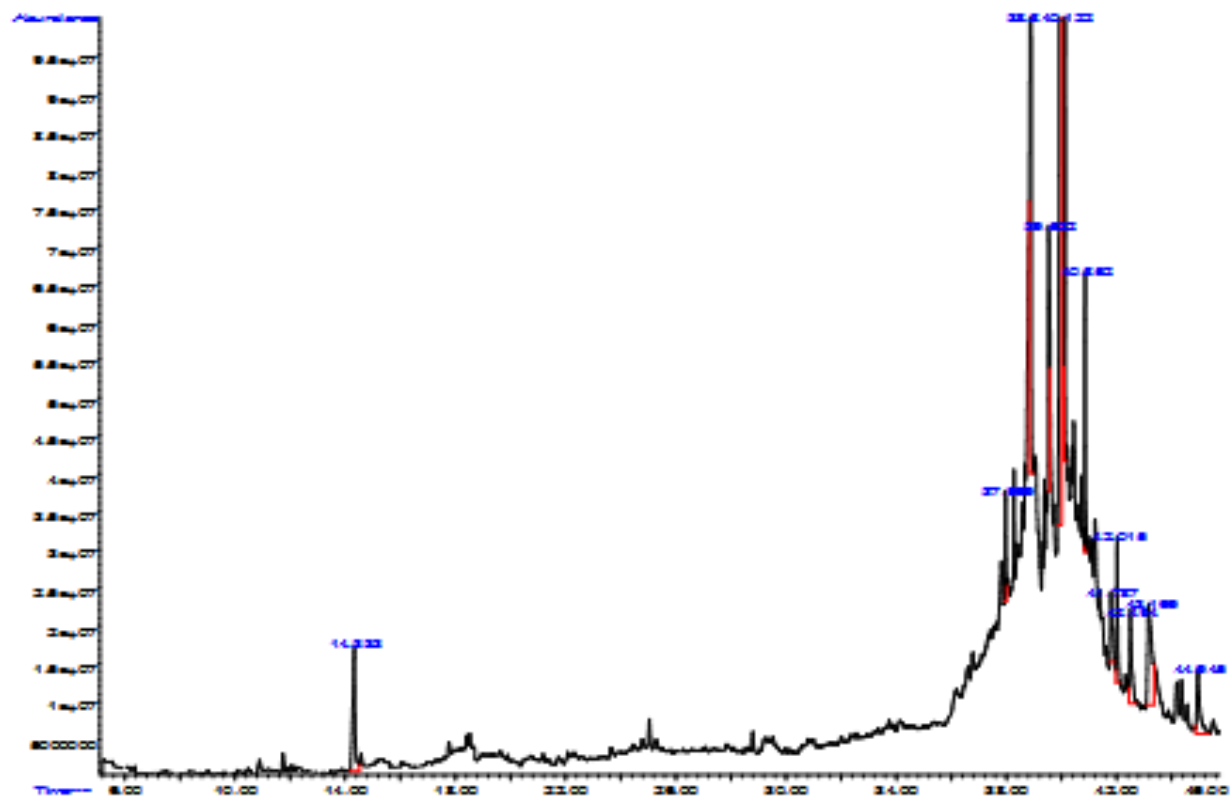

Fig. 2. Gas chromatogram of Ganoderma lucidum ethanolic extract.

Table 2. Bioactive compounds identified in Ganoderma lucidum ethanolic extract.

\begin{tabular}{|c|c|c|c|c|c|}
\hline $\mathrm{S} / \mathrm{N}$ & $\begin{array}{l}\text { Retention } \\
\text { Time }\end{array}$ & $\begin{array}{l}\text { Peak } \\
(\%)\end{array}$ & Name of Compound & $\begin{array}{l}\text { Molecular } \\
\text { Formula }\end{array}$ & $\begin{array}{l}\text { Molecular } \\
\text { Weight }(\mathrm{g} / \mathrm{mol})\end{array}$ \\
\hline 1 & 14.33 & 4.95 & Guaiacol & $\mathrm{C}_{7} \mathrm{H}_{8} \mathrm{O}_{2}$ & 124.14 \\
\hline 2 & 37.97 & 1.81 & Ethyl Pentadecanoate & $\mathrm{C}_{17} \mathrm{H}_{34} \mathrm{O}_{2}$ & 270.45 \\
\hline 3 & 38.87 & 18.09 & $\begin{array}{l}\text { Ethyl hexadecanoate (Ethyl } \\
\text { palmitate) }\end{array}$ & $\mathrm{C}_{18} \mathrm{H}_{36} \mathrm{O}_{2}$ & 284.48 \\
\hline 4 & 39.53 & 3.13 & $\begin{array}{l}\text { Methyl 9-cis,12-cis- } \\
\text { octadecadienoate (Methyl } \\
\text { lineolate) }\end{array}$ & $\mathrm{C}_{19} \mathrm{H}_{34} \mathrm{O}_{2}$ & 294.48 \\
\hline 5 & 39.99 & 45.95 & Ethyl octadeca-9,12-dienoate & $\mathrm{C}_{20} \mathrm{H}_{36} \mathrm{O}_{2}$ & 308.50 \\
\hline 6 & 40.12 & 5.37 & Octadecanoic acid (Stearic acid) & $\mathrm{C}_{18} \mathrm{H}_{36} \mathrm{O}_{2}$ & 284.48 \\
\hline 7 & 40.85 & 3.31 & Ethylcyclohexane & $\mathrm{C}_{8} \mathrm{H}_{16}$ & 112.22 \\
\hline 8 & 41.79 & 2.06 & $\begin{array}{l}\text { Hexadecanoic acid, 2-hydroxyl-1- } \\
\text { (hydroxymethyl)ethyl ester }\end{array}$ & $\mathrm{C}_{19} \mathrm{H}_{38} \mathrm{O}_{4}$ & 330.50 \\
\hline 9 & 42.05 & 2.45 & Bis (2-ethylhexyl)phthalate & $\mathrm{C}_{24} \mathrm{H}_{38} \mathrm{O}_{4}$ & 390.56 \\
\hline 10 & 42.49 & 3.15 & Creatinine & $\mathrm{C}_{4} \mathrm{H}_{7} \mathrm{~N}_{3} \mathrm{O}$ & 113.12 \\
\hline 11 & 43.17 & 6.57 & $\begin{array}{l}\text { 9,12-Octadecadienoyl chloride (z, } \\
\text { z) }\end{array}$ & $\mathrm{C}_{18} \mathrm{H}_{31} \mathrm{ClO}$ & 298.90 \\
\hline 12 & 44.95 & 3.17 & $\begin{array}{l}\text { 3, alpha, 5-cyclo-5, alpha, - } \\
\text { ergosta-6, 8(14), 22t-triene }\end{array}$ & $\mathrm{C}_{28} \mathrm{H}_{42}$ & 378.64 \\
\hline
\end{tabular}


Table 3. Biological activities of bioactive compounds in Ganoderma lucidum ethanolic extract.

\begin{tabular}{|c|c|c|c|}
\hline & Name of Compound & $\begin{array}{l}\text { Chemical } \\
\text { Nature }\end{array}$ & Activities \\
\hline 1 & Guaiacol (2-Methoxyphenol) & $\begin{array}{l}\text { Phenolic } \\
\text { compound }\end{array}$ & $\begin{array}{l}\text { Antioxidant (superoxide free radicals), } \\
\text { Stimulant expectorant, flavoring and } \\
\text { gumming agent }[23,24]\end{array}$ \\
\hline 2 & Ethyl Pentadecanoate & Fatty acid ester & Food additive as flavoring agent $[25]$ \\
\hline 3 & $\begin{array}{l}\text { Ethyl hexadecanoate (Ethyl } \\
\text { palmitate) }\end{array}$ & Stearic acid & $\begin{array}{l}\text { Antifungal, Antitumor and } \\
\text { Antibacterial [21] }\end{array}$ \\
\hline 4 & $\begin{array}{l}\text { Methyl 9-cis,12-cis-octadecadienoate } \\
\text { (Methyl lineolate) }\end{array}$ & $\begin{array}{l}\text { linoleic methyl } \\
\text { ester }\end{array}$ & $\begin{array}{l}\text { Oxidation/peroxidation assay, } \\
\text { Antioxidant additive in biodiesel [26] }\end{array}$ \\
\hline 5 & Ethyl octadeca-9,12-dienoate & $\begin{array}{l}\text { Polyenoic fatty } \\
\text { acid }\end{array}$ & $\begin{array}{l}\text { Hepatoprotective, Antihistaminic, } \\
\text { Hypocholesterolemic, Anti-eczemic } \\
{[20]}\end{array}$ \\
\hline 6 & Octadecanoic acid (Stearic acid) & Fatty acid & $\begin{array}{l}\text { Production of detergent, soap, } \\
\text { cosmetics such as shampoos [27] }\end{array}$ \\
\hline 7 & Ethylcyclohexane & Cycloalkane & Organic solvent [28] \\
\hline 8 & $\begin{array}{l}\text { Hexadecanoic acid,2-hydroxyl-1- } \\
\text { (hydroxymethyl)ethyl ester }\end{array}$ & $\begin{array}{l}\text { Amino } \\
\text { compound }\end{array}$ & $\begin{array}{l}\text { Hemolytic, pesticide, flavor and } \\
\text { antioxidant [21] }\end{array}$ \\
\hline 9 & Bis (2-ethylhexyl)phthalate & Phthalate & Plasticizer \\
\hline 10 & Creatinine & Creatine & $\begin{array}{l}\text { Antimicrobial } \\
\text { Immunosuppressive }[29,30]\end{array}$ \\
\hline 11 & $\begin{array}{l}\text { 9,12-Octadecadienoyl chloride } \\
(\mathrm{z}, \mathrm{z})\end{array}$ & $\begin{array}{l}\text { Linoleic acid } \\
\text { chloride }\end{array}$ & $\begin{array}{l}\text { Nematicide, Antihistaminic, } \\
\text { Anticoronary, Insectifuge, } \\
\text { Antieczemic, Anticancer and } \\
\text { Hypocholesterolemic agents [31]. }\end{array}$ \\
\hline 12 & $\begin{array}{l}\text { 3, alpha., 5-cyclo-5, alpha, - } \\
\text { ergosta-6, } 8(14), 22 \text {-triene }\end{array}$ & Not Available & Not Available \\
\hline
\end{tabular}

\section{Conclusion}

Ganoderma lucidum is nutritionally important as it contains essential dietary elements. The quality makes the mushroom to be used as dietary supplement. GC-MS analysis unveils the bioactive compounds in GLE which revealed ethyl octadeca-9,12-dienoate as the dominant bioactive compound. If intensively explored, the mushroom will be a good candidate in pharmaceutical and nutraceutical fields. Further research is suggested to ascertain the toxicity profile of GLE so that its essentiality will be fully ascertained.

\section{References}

1. S. T. Chang and J. A. Buswell, World J. of Microbiol. Biotechnol. 12, 473 (1996). https://doi.org/10.1007/BF00419460

2. D. N. Roy, A. K. Azad, F. Sultana, A. S. M. Anisuzzaman, and P. Khondkar, The J. Phytopharmacol. 4, 217 (2015).

3. F. Yang, Y. Ke, and S. Kuo, Enzyme Microbial Technol. 27, 295 (2000). https://doi.org/10.1016/S0141-0229(00)00213-1

4. R. Russell and M. Paterson, Phytochemistry 67, 1985 (2006). https://doi.org/10.1016/j.phytochem.2006.07.004

5. N. Benkeblia, J. Food Nutrit. Dietetics 1, 1 (2015).

6. J. Dora and V. Hena, J. Pharmacy Biolog. Sci. 11, 59 (2016). 
7. S. Mahendran, K. T. K. Anandapandian, T. Shankar, C. Chellaram, and P. Vijayabaskar, J. Innov. Developments 8, 1 (2012).

8. B. K. Kim, H. Y. Cho, J. S. Kim, H. W. Kim, and E. C. Choi, Kor. J. Pharmacol. 24, 203 (1993).

9. K. C. Kim and I. G. Kim, Int. J. Mol. Med. 4, 273 (1999).

10. D. Cör, Ž. Knez, and M. K. Hrnčič, Molecules 23, 1 (2018). https://doi.org/10.3390/molecules23030649

11. X. Zhou, J. Lin, Y. Yin, J. Zhao, X. Sun, and K. Tang., Am. J. Chin. Med. 35, 559 (2007). https://doi.org/10.1142/S0192415X07005065

12. O. Taofiq, S. A. Heleno, R. C. Calhelha, M. J. Alves, L. Barros, A. M. Gonzalez-Paramas, M. F. Barreiro, and I. C. F. R. Ferreira, Food Chem. Toxicol. 108, 139 (2017). https://doi.org/10.1016/j.fct.2017.07.051

13. AOAC, Official Methods of Analysis of the Association of Official Analytical Chemists, $16^{\text {th }}$ Edition (Gaithersburg, USA: AOAC International, 2016).

14. S. Sharif, G. Mustafa, H. Munir, C. M. Weaver, Y. Jamil, and M. Shahid, J. Food Nutrit. Res. 4, 703 (2016).

15. S. Salamat, M. Shahid, and J. Najeeb, Int. J. Chem. Studies 5, 297 (2017).

16. A. Colak, Z. Faiz, and E. Sesli, Turk. J. Biochem. 34, 25 (2009).

17. M. K. Zahid, S. Barua, and S. M. Huq, Bangl. J. Nutrit. 22, 61 (2010).

18. R. Mukhopadhyay and A. K. Guha, LWT- Food Sci. Technol. 61, 339 (2015). https://doi.org/10.1016/j.1wt.2014.12.055

19. P. Ragavendran, D. Sophia, C. A. Raj, and V. K. Gopalakrishnan, Pharmacologyonline 1, 358 (2011).

20. L. Wu, H. Gao, X. Wang, J. Ye, J. Lu, and Y. Liang, J. Med. Plants Res. 4, 421 (2010).

21. T. Tyagi and M. Agarwal, J. Pharmacognosy Phytochem. 6, 195 (2017).

22. B. S. Sanodiya, G. Thakur, and R. K. Baghel, Curr. Pharm. Biotechnol. 10, 717 (2009). https://doi.org/10.2174/138920109789978757

23. R. Tisserand and R. Young, Essential Oil Safety, $2^{\text {nd }}$ Edition (Elsevier, 2014). pp. 483-647. https://doi.org/10.1016/B978-0-443-06241-4.00014-X

24. F. Patty, Industrial Hygiene and Toxicology, $2^{\text {nd }}$ Edition (New York: Interscience Publishers, 1963).

25. NCBI, Ethyl Pentadecanoate, CID=38762, PubChem Database, (2019). (Accessed June 19, 2019). https://pubchem.ncbi.nlm.nih.gov/compound/Ethyl-pentadecanoate

26. H. Sutanto, L. Ainny, Lukman, B. H. Susanto, and M. Nasikin, IOP Conf. Series: Mater. Sci. Eng. 316, Article ID 012019 (2018). https://doi.org/10.1088/1757-899X/316/1/012019

27. Z. Zhen, T. F. Xi, and Y. F. Zheng, Surface Modification by Natural Biopolymer Coatings on Magnesium Alloys for Biomedical Applications (Woodhead Publishing Series in Biomaterials, 2015). https://doi.org/10.1016/B978-1-78242-078-1.00011-6

28. NCBI, Ethylcyclohexane, PubChem Database (2019). (Accessed June 19, 2019). https://pubchem.ncbi.nlm.nih.gov/compound/15504

29. T. McDonald, K. M. Drescher, A. Weber, and S. Tracy, The J. Antibiotics 63, 153 (2012). https://doi.org/10.1038/ja.2011.131

30. S. Smithee, S. Tracy, K. M. Drescher, L. A. Pitz, and T. McDonald, J. Microbiolog. Methods 105, 155 (2014). https://doi.org/10.1016/j.mimet.2014.07.023

31. R. Prabakaran, T. S. Kumar, and M. V. Rao, Am. J. Phytomedicine Clinic. Therapeutics 2, 723 (2014). 